Check for updates

Cite this: RSC Adv., 2018, 8, 21926

Received 27th March 2018

Accepted 5th June 2018

DOI: $10.1039 / \mathrm{c} 8 \mathrm{ra02656d}$

rsc.li/rsc-advances

\section{Synthesis of high cis-1,4 polybutadiene with narrow molecular weight distribution via a neodymium- based binary catalyst}

\begin{abstract}
Jie Liu, (D) Xiaodong Fan, ${ }^{*}$ Xin Min, Xiuzhong Zhu, Na Zhao and Zichao Wang
This work explores the synthesis of polybutadiene (PB) with high cis-1,4 unit content and narrow molecular weight distribution using a neodymium-based complex, consisting of neodymium(III) trifluoromethane sulfonate $\left(\mathrm{Nd}_{(}\left(\mathrm{CF}_{3} \mathrm{SO}_{3}\right)_{3}\right)$ and coordinated with tris(2-ethylhexyl)phosphate (TOP). The complex's composition and structure are characterized by elemental analysis, XPS and FT-IR. Combined with Al(i$\mathrm{Bu}_{3}$, a binary catalyst is obtained and then applied to initiate the polymerization of butadiene. Results indicate that the catalyst system displays a high catalyst activity and the product polymer (PB) features a high cis-1,4 content (98.8\%) and a remarkably narrow molecular weight distribution $\left(M_{w} / M_{n}=1.32\right)$. Compared with PB initiated by the current well-studied catalyst $\mathrm{Nd}\left(\mathrm{CF}_{3} \mathrm{SO}_{3}\right)_{3} * 3 \mathrm{TBP} / \mathrm{Al}(\mathrm{i}-\mathrm{Bu})_{3}$, the $\mathrm{Nd}\left(\mathrm{CF}_{3} \mathrm{SO}_{3}\right)_{3}$ *3TOP allows significantly narrowing the molecular weight distribution of the PB, because the $\mathrm{Nd}\left(\mathrm{CF}_{3} \mathrm{SO}_{3}\right)_{3}$ *3TOP is more easily dissolved in hexane. Therefore, butadiene was polymerized in a homogenous system and each monomer's polymerization was initiated in the single molecular state.
\end{abstract}

\section{Introduction}

Butadiene rubber ( $\mathrm{PB}$, high cis-1,4 unit) is one of the most important synthetic rubbers after styrene-butadiene rubber. Due to its regularity and highly linear molecular structure, butadiene rubber exhibits unique properties such as excellent elasticity, low heat built-up and strong resistance versus abrasive and fatigue stress. ${ }^{\mathbf{1}, 2}$ Recently it was shown that the cis-1,4 unit content in PB is an extremely important factor and is beneficial for the strain-induced crystallization of rubbers. ${ }^{3-5}$ Consequently, by increasing the cis-1,4 unit content, not only are PB's tensile strength and elongation ratio mutually increased, but the fatigue and crack resistance are also significantly improved., ${ }^{6,7}$ Therefore, strategies urgently need to be developed to raise the cis-1,4 unit content in PB rubbers. In parallel to this aspect, studies are devoted to narrowing the $\mathrm{PB}$ molecular weight distribution $\left(M_{\mathrm{w}} / M_{\mathrm{n}}<3.0\right)$, which was directly related to the uniformity of the vulcanized cross-linked network, and was shown to strongly affect the physical properties of $\mathrm{PB} .{ }^{8-15}$ Recent research showed that $\mathrm{PB}$ with high molecular weight, narrow molecular weight distribution $(<1.1)$ and high cis-1,4-regularity ( $>99 \%$ ) could be synthesized by using a series of cationic alkyl rare-earth metal catalysts. However, these catalysts are very complicated and expensive, which limited the industrial application of the catalysts. ${ }^{16-19}$

The Key Laboratory of Space Applied Physics and Chemistry, Ministry of Education, Shaanxi Key Laboratory of Macromolecular Science and Technology, School of Science, Northwestern Polytechnical University, Xi'an, 710072, P. R. China. E-mail: xfand@126.com
Neodymium sulphonate is a simple and easily obtained rare earth compound, having the advantage of possessing a high catalytic activity and good directional function for the butadiene polymerization. It was already reported ${ }^{20,21}$ that rare earth based binary catalysts can be synthesized by combining neodymium sulphonate with alkyl aluminum. Recently, $\mathrm{Hu}$ and his team ${ }^{22}$ synthesized the complex $\mathrm{Nd}\left(\mathrm{CF}_{3} \mathrm{SO}_{3}\right)_{3} * 3 \mathrm{TBP}$ using neodymium(III) trifluoromethane sulfonate $\left(\mathrm{Nd}\left(\mathrm{CF}_{3} \mathrm{SO}_{3}\right)_{3}\right)$ and tributyl phosphate (TBP) under reflux in THF. After combining this compound with $\mathrm{Al}(\mathrm{i}-\mathrm{Bu})_{3}$, a binary catalyst was formed which was shown to effectively initiate the polymerization of butadiene. Furthermore, cis-1,4 unit content in the product was demonstrated to be up to $99 \%$. Unfortunately, the associated molecular weight distribution $\left(M_{\mathrm{w}} / M_{\mathrm{n}}>5\right)$ was relatively broad. The authors concluded that as $\mathrm{Nd}\left(\mathrm{CF}_{3} \mathrm{SO}_{3}\right)_{3}{ }^{*} 3 \mathrm{TBP}$ was difficult to be thoroughly dissolved in aliphatic solvent, the obtained catalyst system might not form a homogeneous solution with butadiene monomers. As a result, the initiation of the polymerization performed in the hetero phase state, which allowed the final product having a broader molecular weight distribution.

Based on the previous results, with the aim of synthesizing PB with both high cis-1,4 unit content and narrow molecular weight distribution in this paper, we developed a new rare earth based catalyst in which $\mathrm{Nd}\left(\mathrm{CF}_{3} \mathrm{SO}_{3}\right)_{3}$ was utilized to synthesize a more stable complex by using a long-alkyl segment compound, tris(2-ethylhexyl)phosphate (TOP). The main purpose was to tentatively enhance the solubility of the complex in cyclohexane. The complex was then combined with $\mathrm{Al}(\mathrm{i}-\mathrm{Bu})_{3}$, and a binary catalyst, $\mathrm{Nd}\left(\mathrm{CF}_{3} \mathrm{SO}_{3}\right)_{3}{ }^{*} 3 \mathrm{TOP} / \mathrm{Al}(\mathrm{i}-\mathrm{Bu})_{3}$, was 
prepared. This catalyst is proved to possess the ability not only to promote the increase of 1,4 unit content but also to effectively narrow the molecular weight distribution of $\mathrm{PB}$. The related structure characterizations of the catalyst and PB are provided, together with the discussions on the relationship between the catalyst properties and the polymer chain propagation mechanism.

\section{Experimental section}

\subsection{Materials}

Neodymium(III)trifluoromethane sulfonate $\left(\mathrm{Nd}\left(\mathrm{CF}_{3} \mathrm{SO}_{3}\right)_{3}, 97 \%\right)$, was purchased from TCI, Japan. Triisobutylaluminum (Al(i$\mathrm{Bu})_{3}, 1 \mathrm{M}$ in hexane) was purchased from J\&K, China, and used as received. Tris(2-ethylhexyl)phosphate (TOP, 98\%), tributylphosphate (TBP, 98\%) and 2,6-di-tert-butyl-p-cresol (Antiager 264, CP) were purchased from Aladdin Bio-Chem Technology, China. 1,3-butadiene (Bd, 1.9 M in hexane) was obtained from Energy, China. Cyclohexane was distilled with calcium hydride and stored with $4 \AA$ molecular sieve for one week before use. Methanol (AR) was used as received.

\subsection{Synthesis of $\mathrm{Nd}\left(\mathrm{CF}_{3} \mathrm{SO}_{3}\right)_{3}{ }^{*} 3 \mathrm{TOP}$ complex}

Under argon atmosphere, $\mathrm{Nd}\left(\mathrm{CF}_{3} \mathrm{SO}_{3}\right)_{3} 1.00 \mathrm{~g}(1.7 \mathrm{mmol})$ and TOP $2.20 \mathrm{~g}$ ( $5.1 \mathrm{mmol})$ were put in a dry three-necked flask. The mixture was then heated to $120{ }^{\circ} \mathrm{C}$ stirred for 12 hours. The product was then washed three times with methanol and dried under vacuum at $60{ }^{\circ} \mathrm{C}$ for 12 hours to obtain a reddish and viscous liquid. The process yield was $90.7 \%$. The resulting product was dissolved in cyclohexane to form a stable complex solution with the concentration of $0.025 \mathrm{M}$.

TOP: IR (KBr, cm ${ }^{-1}$ ): 2961, 2930, 2866, 1464, 1283, 1026. $\mathrm{Nd}\left(\mathrm{CF}_{3} \mathrm{SO}_{3}\right)_{3}$ *3TOP: IR $\left(\mathrm{KBr}, \mathrm{cm}^{-1}\right): 2961,2930,2866,1464$, 1225, 1032, 636. Anal. calcd for $\mathrm{C}_{75} \mathrm{H}_{153} \mathrm{O}_{21} \mathrm{P}_{3} \mathrm{NdS}_{3} \mathrm{~F}_{9}$ : C, 47.53\%; S, 5.08\%; H, 8.14\%. Found: C, 46.98\%; S, 5.19\%; H, 7.96\%.

\subsection{Synthesis of $\mathrm{Nd}\left(\mathrm{CF}_{3} \mathrm{SO}_{3}\right)_{3}{ }^{*} 3 \mathrm{TBP}$ complex}

For comparison, we synthetized the $\mathrm{Nd}\left(\mathrm{CF}_{3} \mathrm{SO}_{3}\right)_{3} * 3 \mathrm{TBP}$ complex under the same conditions. In argon atmosphere, $1.00 \mathrm{~g}(1.7 \mathrm{mmol})$ of $\mathrm{Nd}\left(\mathrm{CF}_{3} \mathrm{SO}_{3}\right)_{3}$ and $1.35 \mathrm{~g}(5.1 \mathrm{mmol})$ of TBP were added in a dried three-necked flask. The mixture was heated to $120^{\circ} \mathrm{C}$ stirred for 12 hours. The product obtained was washed with methanol three times and dried under vacuum at $60{ }^{\circ} \mathrm{C}$ for 12 hours to obtain a viscously reddish liquid. The process yield was $92.5 \%$. The resulting complex was dissolved in cyclohexane to give a catalyst mixture solution with the concentration of $0.025 \mathrm{M}$.

TBP: IR (KBr, cm ${ }^{-1}$ ): 2963, 2930, 2874, 1464, 1279, 1029. $\mathrm{Nd}\left(\mathrm{CF}_{3} \mathrm{SO}_{3}\right)_{3}$ *3TBP: IR $\left(\mathrm{KBr}, \mathrm{cm}^{-1}\right): 2962,2935,2873,1463$, 1223, 1033, 638. Anal. calcd for $\mathrm{C}_{39} \mathrm{H}_{81} \mathrm{O}_{21} \mathrm{P}_{3} \mathrm{NdS}_{3} \mathrm{~F}_{9}$ : C, 33.69\%; S, 6.92\%; H, 5.87\%. Found: C, 33.46\%; S, 6.98\%; H, 5.83\%.

\subsection{Preparation of binary catalyst and polymerization of PB}

All synthesis operations were conducted in dry argon atmosphere. The detailed typical polymerization procedure is provided in Table 1 (run 2). Specifically, a binary catalyst
Table 1 XPS data for $\mathrm{Nd}\left(\mathrm{CF}_{3} \mathrm{SO}_{3}\right)_{3}$, complex of $\mathrm{Nd}\left(\mathrm{CF}_{3} \mathrm{SO}_{3}\right)_{3}$ *3TOP and $\mathrm{Nd}\left(\mathrm{CF}_{3} \mathrm{SO}_{3}\right)_{3} * 3 \mathrm{TBP}$

\begin{tabular}{|c|c|c|c|c|c|}
\hline \multirow[b]{3}{*}{ Compound } & \multicolumn{5}{|c|}{ Bonding energy (eV) } \\
\hline & \multirow{2}{*}{$\frac{\mathrm{Nd} 3 \mathrm{~d}_{5 / 2}}{\mathrm{Nd}-\mathrm{O}}$} & \multicolumn{3}{|l|}{ O 1s } & \multirow{2}{*}{$\frac{\mathrm{P} 2 \mathrm{p}}{\mathrm{P}-\mathrm{O}}$} \\
\hline & & $\mathrm{Nd}-\mathrm{O}-\mathrm{S}$ & $\mathrm{S}=\mathrm{O}$ & $\mathrm{P}-\mathrm{O}$ & \\
\hline $\mathrm{Nd}\left(\mathrm{CF}_{3} \mathrm{SO}_{3}\right)_{3}$ & 980.5 & 529.7 & 530.7 & - & - \\
\hline $\mathrm{Nd}\left(\mathrm{CF}_{3} \mathrm{SO}_{3}\right)_{3} * 3 \mathrm{TOP}$ & 978.5 & 530.9 & 531.8 & 532.4 & 133.5 \\
\hline $\mathrm{Nd}\left(\mathrm{CF}_{3} \mathrm{SO}_{3}\right)_{3} * 3 \mathrm{TBP}$ & 978.6 & 531.0 & 531.3 & 532.5 & 133.7 \\
\hline
\end{tabular}

solution was prepared in a Schlenk tube with a rubber septum by the following procedure: butadiene $(0.16 \mathrm{~mL}, 1.9 \mathrm{M}$ solution in hexane), $\mathrm{Nd}\left(\mathrm{CF}_{3} \mathrm{SO}_{3}\right)_{3}{ }^{*} 3 \mathrm{TOP}(0.4 \mathrm{~mL}, 0.025 \mathrm{M}$ solution in cyclohexane $)$ and $\mathrm{Al}(\mathrm{i}-\mathrm{Bu})_{3}(0.2 \mathrm{~mL})$ with $[\mathrm{Al}] /[\mathrm{Nd}]=20$ were mixed in the reaction tube and aged with stirring at $50{ }^{\circ} \mathrm{C}$ for 15 min to obtain a yellowish catalyst solution.

Then butadiene (10.5 mL, 1.9 M solution in hexane) with $([\mathrm{Bd}] /[\mathrm{Nd}]=2000)$ was injected, using a medical injector, into the Schlenk tube filled with the binary catalyst solution (0.013 M, 0.76 mL). The polymer synthesis was carried out at $20{ }^{\circ} \mathrm{C}$ for 2 hours and then quenched by adding $2 \mathrm{~mL}$ ethanol containing 2,6-di-tert-butyl-p-cresol ( $1 \mathrm{wt} \%$ ) as a stabilizer. The product was precipitated in methanol and repeatedly washed with ethanol. The product was dried under vacuum at $40{ }^{\circ} \mathrm{C}$ to reach a constant weight. Finally, a white solid was obtained. The polymerization yield was $88.2 \%$.

\subsection{Characterization of the catalyst structure}

$\mathrm{X}$-ray photoelectron spectroscopy (XPS) was carried to measure the composition of the complexes including $\mathrm{Nd}\left(\mathrm{CF}_{3} \mathrm{SO}_{3}\right)_{3}$ *3TOP, $\mathrm{Nd}\left(\mathrm{CF}_{3} \mathrm{SO}_{3}\right)_{3}{ }^{*} 3 \mathrm{TBP}$ and the pure $\mathrm{Nd}\left(\mathrm{CF}_{3} \mathrm{SO}_{3}\right)_{3}$ compound. The instrument's model is K-Alpha spectrometer (Axis Ultra, Kratos Analytical Ltd., U.K.). A monochromatic Al Ka with $150 \mathrm{~W}$ working power was used as the X-ray source $(h \nu=$ $1486.7 \mathrm{eV})$. Binding energies were referred to the adventitious hydrocarbon C 1s line at $285.0 \mathrm{eV}$.

Bruker Nicolet iS10 FT-IR spectrophotometer was used to compare the structural modification of complexes between TOP and TBP before and after coordinating the molecular interaction. The sample preparation consisted on coating a $\mathrm{KBr}$ disc with the complex solution, and then followed by the evaporation of cyclohexane.

Elementar Vario III elemental analyzer was employed for elemental analysis on the complexes.

${ }^{31} \mathrm{P}$ NMR spectra of $\mathrm{Nd}\left(\mathrm{CF}_{3} \mathrm{SO}_{3}\right)_{3}$ *3TOP was recorded with Bruker $400 \mathrm{MHz}$ at room temperature using DMSO as the solvent and tetramethylsilane (TMS) as the internal reference. The ${ }^{1} \mathrm{H}$ NMR spectra of $\mathrm{La}\left(\mathrm{CF}_{3} \mathrm{SO}_{3}\right) * 3$ TOP with $\mathrm{Al}(\mathrm{i}-\mathrm{Bu})_{3}$ were recorded with Bruker $400 \mathrm{MHz}$ using $\mathrm{C}_{6} \mathrm{D}_{6}$ as the solvent and tetramethylsilane (TMS) as the internal reference.

\subsection{Characterization of PB}

The cis-1,4 unit content in PB was determined by FT-IR analysis to measure. The content of cis-1,4, trans-1,4 and 1,2-unit were 
measured via IR absorption bands at 738, 967 and $911 \mathrm{~cm}^{-1}$, respectively. The calculation equations were used as reported in the literature. ${ }^{23}$

${ }^{1} \mathrm{H}$ NMR spectra were recorded with Bruker $400 \mathrm{MHz}$ using $\mathrm{CDCl}_{3}$ as the solvent and tetramethylsilane (TMS) as the internal reference at room temperature.

The number-average molecular weights and polydispersity indices $\left(M_{\mathrm{w}} / M_{\mathrm{n}}\right)$ of PBs were determined from DAWN EOS size exclusion chromatography/multi-angle light scatter instrument (SEC-MALLS, Wyatt Technology). We used HPLC grade THF as the eluent at a flow rate of $0.5 \mathrm{~mL} \min ^{-1}$ at $25{ }^{\circ} \mathrm{C}$.

\section{Results and discussion}

\subsection{Catalyst synthesis and characterization}

In order to improve the solubility of $\mathrm{Nd}\left(\mathrm{CF}_{3} \mathrm{SO}_{3}\right)_{3} * 3 \mathrm{TBP}$ and narrow the resulting $\mathrm{PB}$ molecular weight distribution, TBP was replaced by TOP, which displays a longer alkyl segment. For purpose of reducing the influence of the solvent THF on the coordination process of $\mathrm{Nd}\left(\mathrm{CF}_{3} \mathrm{SO}_{3}\right)_{3}$ and ligand TOP, thereby forming a well-defined complex in the solvent, $\mathrm{Nd}\left(\mathrm{CF}_{3} \mathrm{SO}_{3}\right)_{3}$ was directly reacted with TOP without addition of any solvent at $120{ }^{\circ} \mathrm{C}$ for 12 hours. Compared to the synthesis route ${ }^{22}$ of $\mathrm{Nd}\left(\mathrm{CF}_{3} \mathrm{SO}_{3}\right)_{3}$ *3TBP which needed refluxing in THF for 12 hours, $\mathrm{Nd}\left(\mathrm{CF}_{3} \mathrm{SO}_{3}\right)_{3}$ *3TOP synthesis approach was much simpler. The resulting product could also be easily dissolved in cyclohexane to form a stable complex solution. The reaction route is presented in Scheme 1.

For verifying the chemical composition of $\mathrm{Nd}\left(\mathrm{CF}_{3} \mathrm{SO}_{3}\right)_{3}-$ *3TOP complex, XPS was employed to conduct the surface characterization, the spectra are shown in Fig. 1, and the data of XPS peak-differentiating are listed in Table 1.

According to the Fig. 1(c) and Table 1, the characteristic P 2p peak in $\mathrm{Nd}\left(\mathrm{CF}_{3} \mathrm{SO}_{3}\right)_{3}{ }^{*} 3 \mathrm{TOP}$ results at $133.5 \mathrm{eV}$, and the deconvolution of the $\mathrm{O}$ 1s spectrum confirmed the presence of $\mathrm{Nd}-\mathrm{O}, \mathrm{S}=\mathrm{O}$ and $\mathrm{P}-\mathrm{O}$ bonding. These results indicated the presence of element phosphorus in the $\mathrm{Nd}\left(\mathrm{CF}_{3} \mathrm{SO}_{3}\right)_{3}{ }^{*} 3 \mathrm{TOP}$ complex. The binding energy $\mathrm{O}$ 1s in $\mathrm{S}=\mathrm{O}$ for $\mathrm{Nd}\left(\mathrm{CF}_{3} \mathrm{SO}_{3}\right)_{3}$ *3TOP was higher than that of in pure $\mathrm{Nd}\left(\mathrm{CF}_{3} \mathrm{SO}_{3}\right)_{3}$, while the binding energy of $\mathrm{Nd} 3 \mathrm{~d}_{2 / 5}$ in $\mathrm{Nd}\left(\mathrm{CF}_{3} \mathrm{SO}_{3}\right)_{3}$ *3TOP was lower than that of in $\mathrm{Nd}\left(\mathrm{CF}_{3} \mathrm{SO}_{3}\right)_{3}$. This result implies that the lone pair electrons of oxygen atom in TOP was successfully coordinated with the neodymium atom. ${ }^{24}$

To further investigate the $\mathrm{Nd}\left(\mathrm{CF}_{3} \mathrm{SO}_{3}\right)_{3}$ *3TOP complex, FT-IR spectra have been analyzed as shown in Fig. 2. Unambiguously, the strong IR absorption peak at $636 \mathrm{~cm}^{-1}$ indicates the existence of $\mathrm{Nd}-\mathrm{O}$ groups in $\mathrm{Nd}\left(\mathrm{CF}_{3} \mathrm{SO}_{3}\right)_{3}{ }^{*} 3 \mathrm{TOP}$, which demonstrates the coordination linkage formation. The IR peak at $1283 \mathrm{~cm}^{-1}$ disappears in the $\mathrm{Nd}\left(\mathrm{CF}_{3} \mathrm{SO}_{3}\right)_{3}{ }^{*} 3 \mathrm{TOP}$ complex while it seen in the original TOP compound. This indicates that the

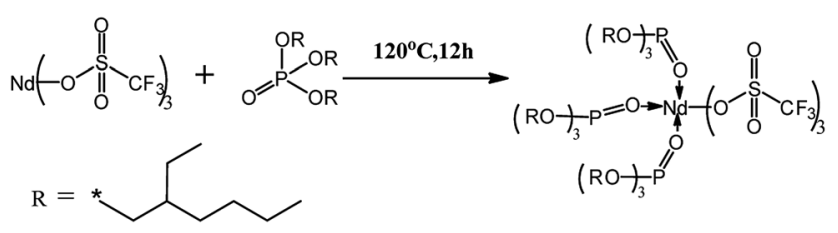

Scheme 1 Synthesis route of $\mathrm{Nd}\left(\mathrm{CF}_{3} \mathrm{SO}_{3}\right)_{3} * 3 \mathrm{TOP}$.

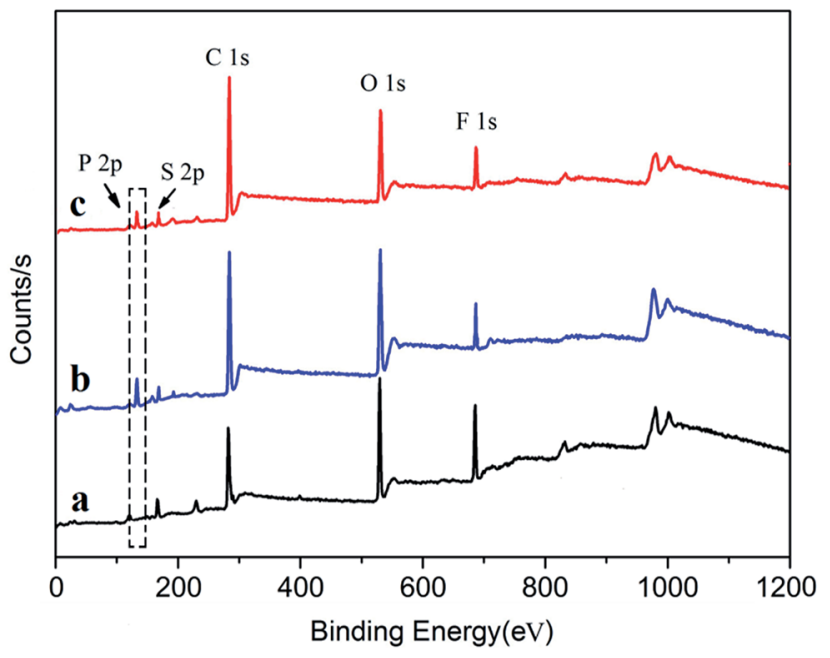

Fig. 1 XPS spectra of complex $\mathrm{Nd}\left(\mathrm{CF}_{3} \mathrm{SO}_{3}\right)_{3} * 3 \mathrm{TOP}, \mathrm{Nd}\left(\mathrm{CF}_{3} \mathrm{SO}_{3}\right)_{3}-$ $* 3 \mathrm{TBP}$ and $\mathrm{Nd}\left(\mathrm{CF}_{3} \mathrm{SO}_{3}\right)_{3}$ compound. (a) Pure $\mathrm{Nd}\left(\mathrm{CF}_{3} \mathrm{SO}_{3}\right)_{3}$ compound. (b) $\mathrm{Nd}\left(\mathrm{CF}_{3} \mathrm{SO}_{3}\right)_{3} * 3 \mathrm{TBP}$. (c) $\mathrm{Nd}\left(\mathrm{CF}_{3} \mathrm{SO}_{3}\right)_{3} * 3 \mathrm{TOP}$.

reaction of TOP and $\mathrm{Nd}\left(\mathrm{CF}_{3} \mathrm{SO}_{3}\right)_{3}$ was complete. Furthermore, these data indicate that there are no free TOP molecules are found in the solution, and that an additional, strong absorption peak appears at $1225 \mathrm{~cm}^{-1}$ reflecting the existence of a coordination interaction between $\mathrm{P}=\mathrm{O}$ and the metal. ${ }^{25}$

To discuss the impact of the solubility of the catalyst on the polymer molecular distribution, we compared the result using $\mathrm{Nd}\left(\mathrm{CF}_{3} \mathrm{SO}_{3}\right)_{3}{ }^{*} 3 \mathrm{TBP}$ and $\mathrm{Nd}\left(\mathrm{CF}_{3} \mathrm{SO}_{3}\right)_{3} * 3 \mathrm{TOP}$. The related XPS characterization is shown in Fig. 1 (b) and Table 1. In $\mathrm{Nd}\left(\mathrm{CF}_{3^{-}}\right.$ $\left.\mathrm{SO}_{3}\right)_{3}$ *3TBP we can observe the appearance of a characteristic peak in the $\mathrm{P} 2 \mathrm{p}$ spectrum at $133.7 \mathrm{eV}$ binding energy, together with the evident change in the $\mathrm{Nd} 3 \mathrm{~d}_{2 / 5}$ and $\mathrm{S} 2 \mathrm{p}(\mathrm{S}=\mathrm{O})$ indicating the formation of coordination linkage between $\mathrm{Nd}\left(\mathrm{CF}_{3}{ }^{-}\right.$ $\left.\mathrm{SO}_{3}\right)_{3}$ and TBP. ${ }^{24}$

${ }^{31} \mathrm{P}$ NMR spectroscopy was used to further detect the structure of the $\mathrm{Nd}\left(\mathrm{CF}_{3} \mathrm{SO}_{3}\right)_{3}{ }^{*} 3 \mathrm{TOP}$. The chemical shift of $\mathrm{P}$ in TBP occurs at $-0.64 \mathrm{ppm}$, and it completely disappeared associated with the appearance at $1.21 \mathrm{ppm}$ (Fig. 3), suggesting that all

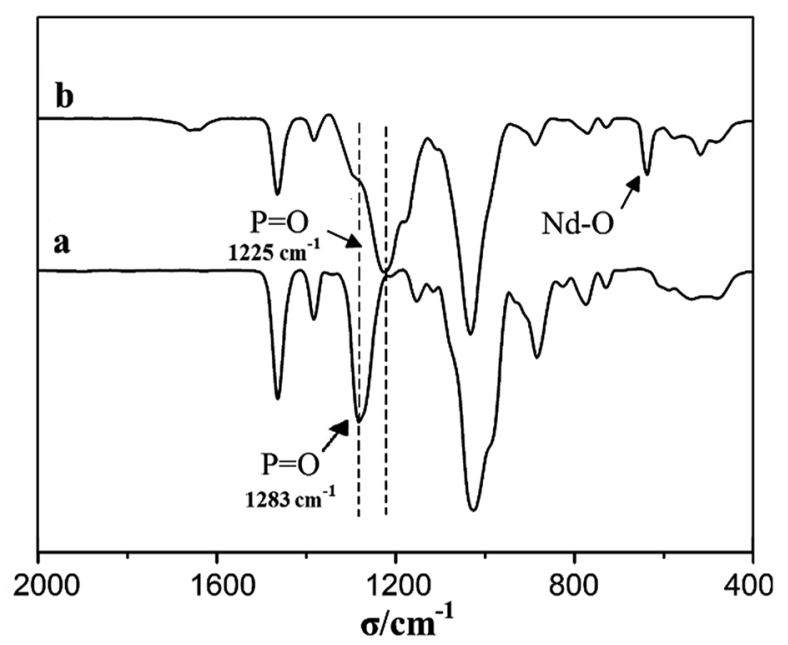

Fig. $2 \mathrm{FI}-\mathrm{TR}$ spectra of complex $\mathrm{Nd}\left(\mathrm{CF}_{3} \mathrm{SO}_{3}\right)_{3} * 3 \mathrm{TOP}$ and ligand TOP. (a). TOP. (b). $\mathrm{Nd}\left(\mathrm{CF}_{3} \mathrm{SO}_{3}\right)_{3} * 3 \mathrm{TOP}$. 

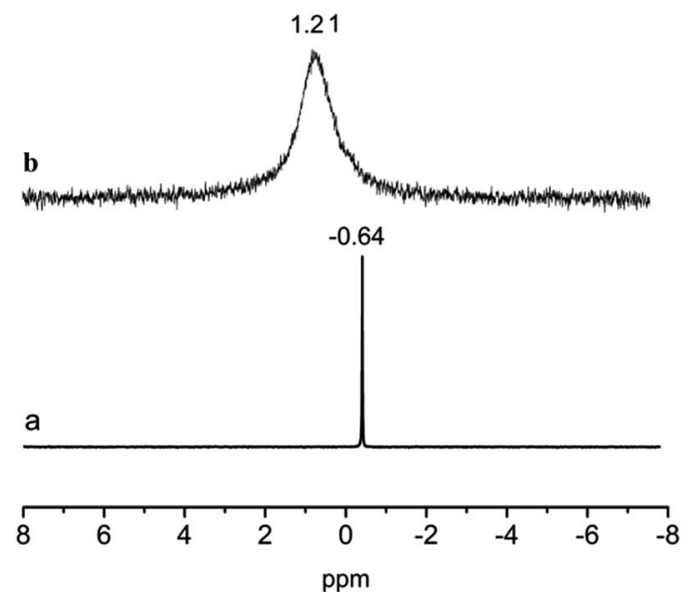

Fig. $3{ }^{31} \mathrm{P}$ NMR spectra of complex $\mathrm{Nd}\left(\mathrm{CF}_{3} \mathrm{SO}_{3}\right)_{3} * 3 \mathrm{TOP}$ and ligand TOP. (a) TOP. (b) $\mathrm{Nd}\left(\mathrm{CF}_{3} \mathrm{SO}_{3}\right)_{3} * 3 T O P$.

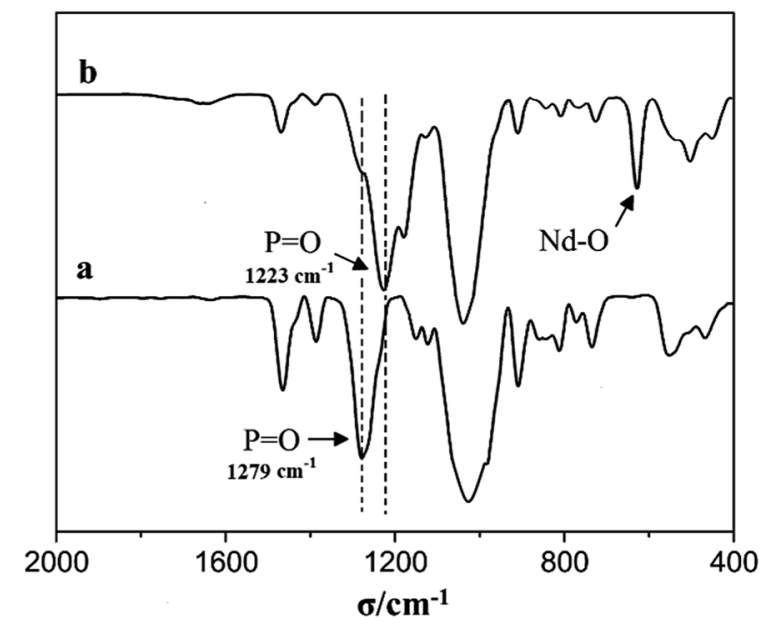

Fig. $4 \mathrm{FI}-\mathrm{TR}$ spectra of complex $\mathrm{Nd}\left(\mathrm{CF}_{3} \mathrm{SO}_{3}\right)_{3} * 3 \mathrm{TBP}$ and ligand TBP (a) TBP. (b) $\mathrm{Nd}\left(\mathrm{CF}_{3} \mathrm{SO}_{3}\right)_{3} * 3 \mathrm{TBP}$.

phosphorus was converted into the newly generated $\mathrm{Nd}\left(\mathrm{CF}_{3}-\right.$ $\left.\mathrm{SO}_{3}\right)_{3}{ }^{*} 3 \mathrm{TOP}$. The change of the chemical shift was attributed to the coordination of ligand TOP to $\mathrm{Nd}\left(\mathrm{CF}_{3} \mathrm{SO}_{3}\right)_{3}$.

The FT-IR spectra of $\mathrm{Nd}\left(\mathrm{CF}_{3} \mathrm{SO}_{3}\right)_{3}{ }^{*} 3 \mathrm{TBP}$ complex are shown in Fig. 4 , the $\mathrm{P}=\mathrm{O}$ characteristic peak in TBP results at about $1279 \mathrm{~cm}^{-1}$, however the strong absorption observed at $1223 \mathrm{~cm}^{-1}$ in $\mathrm{Nd}\left(\mathrm{CF}_{3} \mathrm{SO}_{3}\right)_{3} * 3 \mathrm{TBP}$, could soundly confirm a coordination linkage structure in $\mathrm{Nd}\left(\mathrm{CF}_{3} \mathrm{SO}_{3}\right)_{3} * 3 \mathrm{TBP}$.

\subsection{Initiation of the polymerization of $\mathrm{Bd}$ via two different catalysts}

Before conducting the polymerization, $\mathrm{Nd}\left(\mathrm{CF}_{3} \mathrm{SO}_{3}\right)_{3} * 3 \mathrm{TOP}$ should be firstly aged with a small amount of butadiene and $\mathrm{Al}(\mathrm{i}-\mathrm{Bu})_{3}$ in hexane, to obtain a homogeneous binary catalyst. To make a comparison, $\mathrm{Nd}\left(\mathrm{CF}_{3} \mathrm{SO}_{3}\right)_{3}{ }^{*} 3 \mathrm{TBP}$ with $\mathrm{Al}(\mathrm{i}-\mathrm{Bu})_{3}$ was also used for the polymerization of $\mathrm{Bd}$. The cis-1,4 unit content and the molecular weight distribution data of PB obtained with two catalysts are presented in Table 2 . The polymerization didn't occur in the absence of TOP or TBP coligands, no polymer was obtained after 24 hours (run 1). In contrast, the two catalysts show a high activity at both $20{ }^{\circ} \mathrm{C}$ and $50{ }^{\circ} \mathrm{C}$ reflecting that in a short time and at relatively low temperature both catalysts could easily initiate the $\mathrm{Bd}$ polymerization. However, $\mathrm{Nd}\left(\mathrm{CF}_{3}\right.$ $\left.\mathrm{SO}_{3}\right)_{3}{ }^{*} 3 \mathrm{TOP} / \mathrm{Al}(\mathrm{i}-\mathrm{Bu})_{3}$ catalyst system demonstrated a higher activity as under the same polymerization conditions, not only the product yield was higher, but also the molecular weight distribution was narrower as can be seen from Table 2 .

To further investigate the difference of the polymer structures prepared by the two catalysts, ${ }^{1} \mathrm{H}$ NMR spectra are presented in Fig. 5, showing that for both PB, we could observe a strong chemical shifts at $5.45 \mathrm{ppm}$ indicating the presence of a high cis-1,4 unit content. Meanwhile, FT-IR spectra in Fig. 6 also show a strong absorption peak at $738 \mathrm{~cm}^{-1}$. According to the calculations of the data in IR spectra, the results demonstrated that trans-1,4 and 1,2-unit contents in both $\mathrm{PB}$ polymers are very low (Table 2 ).

As showed in Fig. 7, the SEC-MALLS curves indicated that both PBs exhibited a mono-modal molecular weight distribution; however, the distribution of $\mathrm{PB}$ using $\mathrm{Nd}\left(\mathrm{CF}_{3} \mathrm{SO}_{3}\right)_{3}{ }^{*} 3 \mathrm{TOP}$ system was much narrower than $\mathrm{Nd}\left(\mathrm{CF}_{3} \mathrm{SO}_{3}\right)_{3}{ }^{*} 3 \mathrm{TBP}$ system.

3.3.1 Initiation mechanism for two binary catalyst systems. As showed in Table 2, polybutadienes synthesized via both catalyst systems display a high cis-1,4 unit content. This is due to neodymium-based catalyst, which increased the coordination effect and the stereo-selectivity. ${ }^{26,27}$ At the same time, $\mathrm{Nd}\left(\mathrm{CF}_{3}\right.$ $\left.\mathrm{SO}_{3}\right)_{3}$ groups have marked electron-withdrawing ability leading to the increase of the coordination and orientation effects of neodymium atom during the polymerization. Therefore, the two catalyst systems are not only efficient for initiating the polymerization of butadiene, but also allow achieving a high cis1,4 unit content $(>98 \%)$ in PB. Referring to the literatures, ${ }^{28-30}$ the detailed steps of monomer addition were described in Scheme 2.

Table 2 Comparison of PB molecular parameters prepared via $\mathrm{Nd}\left(\mathrm{CF}_{3} \mathrm{SO}_{3}\right)_{3} * 3 \mathrm{TOP}$ and $\mathrm{Nd}\left(\mathrm{CF}_{3} \mathrm{SO}_{3}\right)_{3} * 3 \mathrm{TBP}$ systems ${ }^{a}$

\begin{tabular}{|c|c|c|c|c|c|c|c|c|}
\hline Run & Binary catalyst & Temperature $\left({ }^{\circ} \mathrm{C}\right)$ & Yield (\%) & $M_{\mathrm{n}} \times 10^{4 e}\left(\mathrm{~g} \mathrm{~mol}^{-1}\right)$ & $M_{\mathrm{w}} / M_{\mathrm{n}}{ }^{e}$ & $c i s-1,4^{f}(\%)$ & trans $-1,4^{f}(\%)$ & $1,2^{f}(\%)$ \\
\hline $1^{b}$ & $\mathrm{Nd}\left(\mathrm{CF}_{3} \mathrm{SO}_{3}\right)_{3}$ & 50 & - & - & - & - & - & - \\
\hline $2^{c}$ & $\mathrm{Nd}\left(\mathrm{CF}_{3} \mathrm{SO}_{3}\right)_{3} * 3 \mathrm{TOP}$ & 20 & 88.2 & 9.8 & 1.32 & 98.8 & 0.5 & 0.7 \\
\hline $4^{c}$ & $\mathrm{Nd}\left(\mathrm{CF}_{3} \mathrm{SO}_{3}\right)_{3} * 3 \mathrm{TBP}$ & 20 & 83.5 & 8.7 & 3.21 & 98.6 & 0.5 & 0.9 \\
\hline $5^{d}$ & $\mathrm{Nd}\left(\mathrm{CF}_{3} \mathrm{SO}_{3}\right)_{3} * 3 \mathrm{TBP}$ & 50 & 86.9 & 9.0 & 3.45 & 98.6 & 0.6 & 0.8 \\
\hline
\end{tabular}

${ }^{a}$ Polymerization conditions: solvent is hexane, $[\mathrm{Nd}]=8.9 \times 10^{-4} \mathrm{~mol} \mathrm{~L}^{-1}$, [Al]/[Nd] $=20,[\mathrm{Bd}] /[\mathrm{Nd}]=2000 .{ }^{b}$ Polymerization time is $24 \mathrm{~h}$.

${ }^{c}$ Polymerization time is $2 \mathrm{~h} .{ }^{d}$ Polymerization time is $30 \mathrm{~min} .{ }^{e}$ Measured by SEC-MALLS. ${ }^{f}$ Measured by FT-IR spectroscopy. 


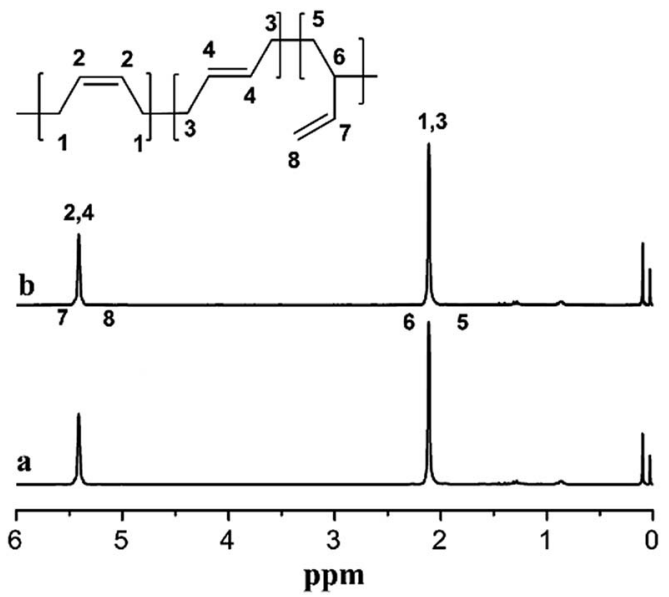

Fig. $5{ }^{1} \mathrm{H}$ NMR spectra of PBs obtained via $\mathrm{Nd}\left(\mathrm{CF}_{3} \mathrm{SO}_{3}\right)_{3} * 3 \mathrm{TOP}$ and $\mathrm{Nd}\left(\mathrm{CF}_{3} \mathrm{SO}_{3}\right)_{3} * 3 \mathrm{TBP}$ systems. (a). $\mathrm{Nd}\left(\mathrm{CF}_{3} \mathrm{SO}_{3}\right)_{3} * 3 \mathrm{TBP}$. (b). $\mathrm{Nd}\left(\mathrm{CF}_{3}-\right.$ $\left.\mathrm{SO}_{3}\right)_{3} * 3 T O P$. Polymerization conditions: in cyclohexane at $20{ }^{\circ} \mathrm{C}$ for $2 \mathrm{~h},[\mathrm{Nd}]=8.9 \times 10^{-4} \mathrm{~mol} \mathrm{~L}^{-1},[\mathrm{Al}] /[\mathrm{Nd}]=20,[\mathrm{Bd}] /[\mathrm{Nd}]=2000$

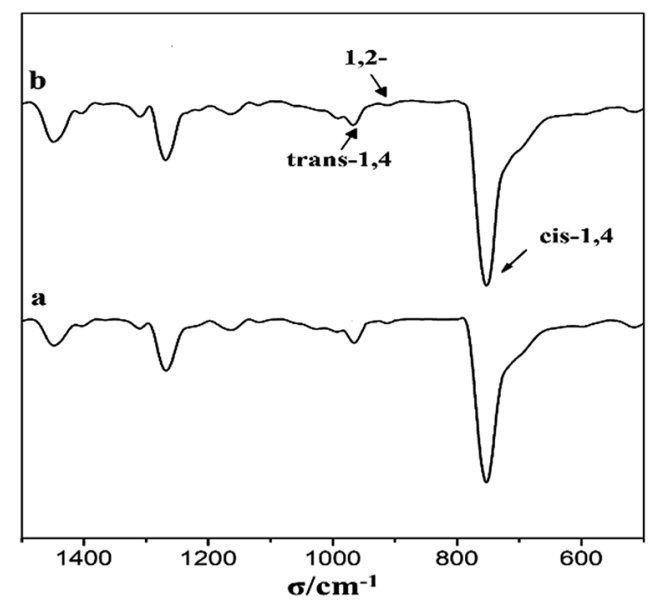

Fig. 6 FT-IR spectra of PB obtained via $\mathrm{Nd}\left(\mathrm{CF}_{3} \mathrm{SO}_{3}\right)_{3} * 3 \mathrm{TOP}$ and $\mathrm{Nd}\left(\mathrm{CF}_{3} \mathrm{SO}_{3}\right)_{3} * 3 \mathrm{TBP}$ systems. (a). $\mathrm{Nd}\left(\mathrm{CF}_{3} \mathrm{SO}_{3}\right)_{3} * 3 \mathrm{TBP}$. (b). $\mathrm{Nd}\left(\mathrm{CF}_{3}-\right.$ $\left.\mathrm{SO}_{3}\right)_{3} * 3 T O P$. Polymerization conditions: in cyclohexane at $20{ }^{\circ} \mathrm{C}$ for $2 \mathrm{~h},[\mathrm{Nd}]=8.9 \times 10^{-4} \mathrm{~mol} \mathrm{~L}^{-1},[\mathrm{Al}] /[\mathrm{Nd}]=20,[\mathrm{Bd}] /[\mathrm{Nd}]=2000$.

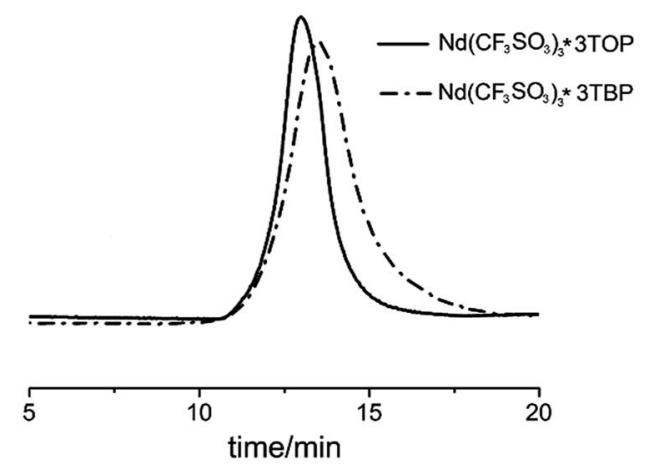

Fig. 7 SEC-MALLS curves of PBs obtained via $\mathrm{Nd}\left(\mathrm{CF}_{3} \mathrm{SO}_{3}\right)_{3} * 3 \mathrm{TOP}$ and $\mathrm{Nd}\left(\mathrm{CF}_{3} \mathrm{SO}_{3}\right)_{3}$ *3TBP systems. Polymerization conditions: in cyclohexane at $20{ }^{\circ} \mathrm{C}$ for $2 \mathrm{~h},[\mathrm{Nd}]=8.9 \times 10^{-4} \mathrm{~mol} \mathrm{~L}^{-1},[\mathrm{Al}] /[\mathrm{Nd}]=20,[\mathrm{Bd}] /$ $[\mathrm{Nd}]=2000$.

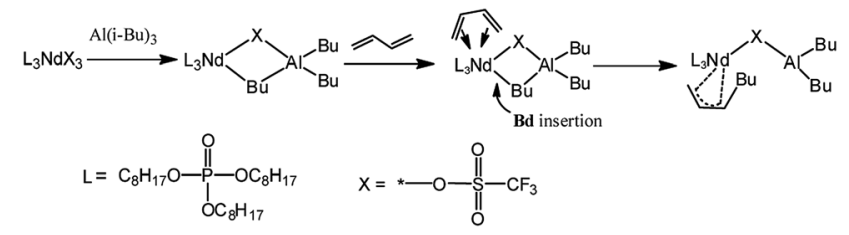

Scheme 2 The monomer addition mechanism via catalyst active center of $\mathrm{Nd}\left(\mathrm{CF}_{3} \mathrm{SO}_{3}\right)_{3} / \mathrm{Al}(\mathrm{i}-\mathrm{Bu})_{3}$ binary system.

Because the $\mathrm{Nd}\left(\mathrm{CF}_{3} \mathrm{SO}_{3}\right)_{3}$ has the paramagnetic property, ${ }^{1} \mathrm{H}$ NMR was used to study the alkylation of complexes by substituting the $\mathrm{Nd}\left(\mathrm{CF}_{3} \mathrm{SO}_{3}\right)_{3}$ with $\mathrm{La}\left(\mathrm{CF}_{3} \mathrm{SO}_{3}\right)_{3}$, as shown in Fig. 8. These two characteristic peaks appeared correspondingly at $\delta 1.40 \mathrm{ppm}$ (a, in Fig. 8) and $\delta 1.79 \mathrm{ppm}$ (b, in Fig. 8) after alkylation of $\mathrm{La}\left(\mathrm{CF}_{3} \mathrm{SO}_{3}\right)_{3}{ }^{*} 3 \mathrm{TOP}$, which also proved the completion of the alkylation. ${ }^{31}$

It was also found from Table 2 that the molecular weight distribution of $\mathrm{PB}$ via $\mathrm{Nd}\left(\mathrm{CF}_{3} \mathrm{SO}_{3}\right)_{3}$ *3TOP was significantly narrower than that via $\mathrm{Nd}\left(\mathrm{CF}_{3} \mathrm{SO}_{3}\right)_{3}{ }^{*} 3 \mathrm{TBP}$. In order to understand the possible reason for this result, two system's external appearances was checked before conducting polymerization as showed in Fig. 9.

Obviously, the $\mathrm{Nd}\left(\mathrm{CF}_{3} \mathrm{SO}_{3}\right)_{3}$ *3TOP system result in a clear and homogeneous state after adding the monomer solution, while the $\mathrm{Nd}\left(\mathrm{CF}_{3} \mathrm{SO}_{3}\right)_{3}{ }^{*} 3 \mathrm{TBP}$ solution was turbid and in a micro-phase separated state. This result is attributed to the fact that TOP ligand has relatively longer alkyl segments with eight carbon atoms, while TBP has only four carbon atoms. Based on the principle of similarity and intermiscibility, the $\mathrm{Nd}\left(\mathrm{CF}_{3} \mathrm{SO}_{3}\right)_{3}$ *3TOP catalyst should display a better solubility in hexane. Moreover, after the addition of monomer solution to this binary catalyst system, monomer and the solvent could be in a completely homogeneous state. The polymerization could proceed from each single initiating active center to conduct the chain propagation and termination. ${ }^{32}$ Consequently, the PB with narrower molecular weight distribution could be successfully achieved. On the contrary, since $\mathrm{Nd}\left(\mathrm{CF}_{3} \mathrm{SO}_{3}\right)_{3}{ }^{*} 3 \mathrm{TBP}$ has a poor solubility in hexane, the catalyst active center are in

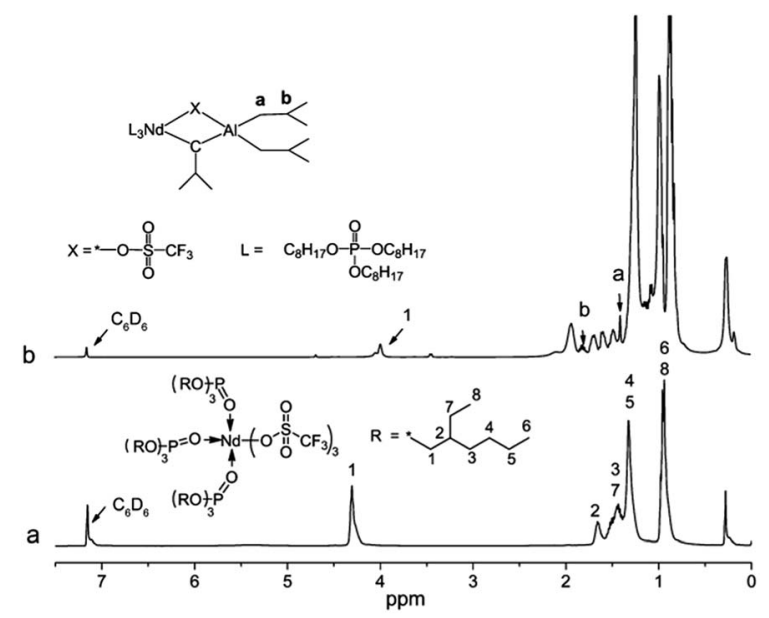

Fig. $8{ }^{1} \mathrm{H}$ NMR of the alkylation process of $\mathrm{La}\left(\mathrm{CF}_{3} \mathrm{SO}_{3}\right)_{3} * 3 \mathrm{TOP}$. (a) $\mathrm{La}\left(\mathrm{CF}_{3} \mathrm{SO}_{3}\right)_{3}$ *3TOP. (b) $\mathrm{La}\left(\mathrm{CF}_{3} \mathrm{SO}_{3}\right)_{3} * 3 \mathrm{TOP}$ with $\mathrm{Al}(\mathrm{i}-\mathrm{Bu})_{3}$. 


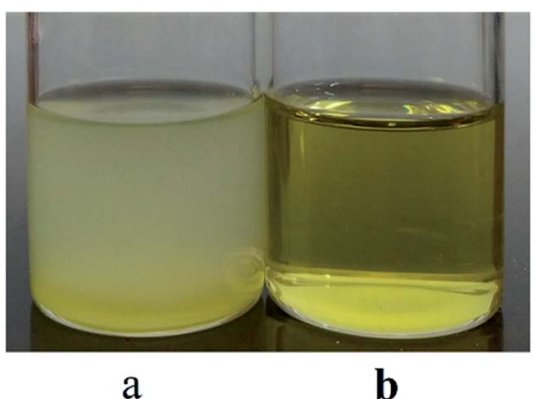

a

b

Fig. 9 Solubility comparison of two catalyst systems with addition of monomer. (a) The state of the $\mathrm{Nd}\left(\mathrm{CF}_{3} \mathrm{SO}_{3}\right)_{3} * 3 \mathrm{TBP} / \mathrm{Al}(\mathrm{i}-\mathrm{Bu})_{3}$ catalyst system. (b) The state of the $\mathrm{Nd}\left(\mathrm{CF}_{3} \mathrm{SO}_{3}\right)_{3} * 3 \mathrm{TOP} / \mathrm{Al}(\mathrm{i}-\mathrm{Bu})_{3}$ catalyst system.

a heterogeneous state. Although these active centers of the particle surface could still initiate the polymerization of butadiene, the heterogeneous state might limit the monomers diffusion to the active center. ${ }^{33}$ As a result, the monomer's initiation and the chain propagation are in a much heterogeneous state which could cause a wider molecular weight distribution.

\section{Conclusions}

A neodymium-based binary catalyst system, $\mathrm{Nd}\left(\mathrm{CF}_{3} \mathrm{SO}_{3}\right)_{3}$ *3TOP/Al(i-Bu $)_{3}$, was designed and synthesized by new process. With the utilization of XPS and FTIR analyses, the catalyst's composition and its coordination structure could be precisely determined. This binary catalyst system was applied to initiate the polymerization of butadiene which confirmed its efficient catalytic activity. The resulting PB product displays not only a high cis-1,4 unit content (98.8\%) but also a remarkably narrow molecular weight distribution $\left(M_{\mathrm{w}} / M_{\mathrm{n}}=1.32\right)$. The high cis-1,4 unit content is attributed to the neodymium-based complex providing for a strong coordination effect and stereo-selectivity. The narrow molecular weight distribution is attributed to the longer alkyl segments in TOP, these segments could be easily dissolved in hexane and created a better homogeneous polymerization environment. These properties can lead to the monomer's initiation and chain propagation at a single molecular stage. Compared with other catalyst systems reported in the current literature, $\mathrm{Nd}\left(\mathrm{CF}_{3} \mathrm{SO}_{3}\right)_{3}{ }^{*} 3 \mathrm{TOP}$ appears as appropriate for future application thanks to its advanced initiation effect and simple preparation method.

\section{Conflicts of interest}

There are no conflicts to declare.

\section{Acknowledgements}

This work was supported by the scientific research project of Ministry of Industry and Information Technology of P. R. China (grant number JSJL2016140B004) and the Key Laboratory Project of Department of Science and Technology of Shaanxi Province, China (grant number 2013SZS17-Z02). The authors declare no competing financial interest.

\section{References}

1 N. M. T. Pires, F. M. B. Coutinho and M. A. S. Costa, Eur. Polym. J., 2004, 40, 2599.

2 N. Oskar, Neodymium-Based Ziegler-Natta Catalysts and their Application in Diene Polymerization, Springer, Berlin, 2006, p. 5.

3 W. Gao and D. M. Cui, J. Am. Chem. Soc., 2008, 130, 4984.

4 Z. C. Zhang, D. M. Cui, B. L. Wang, B. Liu and Y. Yang, Polymerization of 1,3-Conjugated Dienes with Rare-Earth Metal Precursors, Springer-Verlag, Berlin Heidelberg, 2010.

5 G. H. Kwag, P. S. Kim, S. Han and H. K. Choi, Polymer, 2005, 46, 3782.

6 X. F. Liu, T. Zhou, Y. C. Liu, A. M. Zhang, C. Y. Yuan and W. D. Zhang, RSC Adv., 2015, 5, 10231.

7 L. X. Zhang, T. Suzuki, Y. Luo, M. Nishiura and Z. M. Hou, Angew. Chem., Int. Ed., 2007, 119, 1941.

8 Y. M. Hu, C. L. Kong, Y. Li, L. Chang, D. D. Xu and Y. R. Wang, Polym. Mater. Sci. Eng., 2011, 27, 9.

9 H. Leicht, I. Göttker-Schnetmann and S. Mecking, Macromolecules, 2017, 50, 8464.

10 D. M. Roitershtein, A. A. Vinogradov, A. A. Vinogradov, K. A. Lyssenko, Y. V. Nelyubina, I. V. Anan, I. E. Nifant'ev, V. A. Yakovlev and N. N. Kostitsyna, Organometallics, 2013, 32, 1272.

11 A. Fischbach, F. Perdih, E. Herdtweck and R. Anwander, Organometallics, 2006, 25, 1626.

12 P. Li, K. Y. Zhang, M. Nishiura and Z. M. Hou, Angew. Chem., Int. Ed., 2011, 50, 12012.

13 C. L. Fan, C. X. Bai, H. G. Cai, Q. Q. Dai, X. Q. Zhang and F. S. Wang, J. Polym. Sci. A Polym. Chem., 2010, 48, 4768.

14 Z. B. Jian, S. J. Tang and D. M. Cui, Chem.-Eur. J., 2010, 16, 14007.

15 S. Kaita, Z. M. Hou and Y. Wakatsuki, Macromolecules, 1999, 32, 9078.

16 L. F. Wang, D. M. Cui, Z. M. Hou, W. Li and Y. Li, Organometallics, 2011, 30, 760.

17 Y. Yang, K. Lv, L. F. Wang, Y. Wang and D. M. Cui, Chem. Commun., 2010, 46, 6150.

18 D. F. Li, S. H. Li, D. M. Cui and X. Q. Zhang, Organometallics, 2010, 29, 2186.

19 L. X. Zhang, T. Suzuki, Y. Luo, N. Masayoshi and Z. M. Hou, Angew. Chem., Int. Ed., 2007, 46, 1909.

20 Q. Q. Dai, X. Q. Zhang, Y. M. Hu, J. Y. He, C. Shi, Y. Q. Li and C. X. Bai, Macromolecules, 2017, 50, 7887.

21 J. Q. Wen, X. Q. Zhang and Q. Q. Dai, Chin. J. Polym. Sci., 2015, 33, 475.

22 Z. Y. Hu, Q. Q. Dai, H. Y. Liu, G. Z. Zhang, Y. Q. Wang, S. X. Chen, S. W. Wang and X. Q. Zhang, China Synth. Rubber Ind., 2014, 37, 96.

23 W. K. E. Schmalz, Rubber Chem. Technol., 1960, 33, 639. 24 L. H. Wang and W. G. Zhang, Acta Polym. Sin., 1997, 2, 25.

25 Y. M. Hu, C. Q. Zhang, X. G. Liu, K. K. Gao, Y. M. Cao, C. Y. Zhang and X. Q. Zhang, J. Appl. Polym. Sci., 2014, 131, 40153. 
26 C. J. Shan, T. Sun, S. F. Feng, X. Z. Ji and S. H. Yang, Acta Polym. Sin., 1989, 06, 709.

27 C. Costabile, G. Milano, L. Cavallo, P. Longo, G. Guerra and A. Zambelli, Polymer, 2004, 45, 467.

28 F. M. B. Coutinho, T. C. J. Rocha, I. L. Mello, D. S. S. Nunes, B. G. Soares and M. A. S. Costa, J. Appl. J. Appl. Polym. Sci., 2005, 98, 2539.
29 Y. T. Jin, X. T. Zhang, F. K. P. Min and Y. Wu, J. Chin. Rare Earth Soc., 1990, 8, 79.

30 F. Wang, C. Y. Zhang, Y. M. Hu, X. Y. Jia, C. X. Bai and X. Q. Zhang, Polymer, 2012, 53, 6027.

31 K. Lv and D. M. Cui, Organometallics, 2010, 29, 2987.

32 C. Y. Ren, G. L. Li, W. M. Dong, L. S. Jiang, X. Q. Zhang and F. S. Wang, Polymer, 2007, 48, 2470.

33 D. J. Wilson and D. K. Jenkins, Polym. Bull., 1992, 27, 407. 